\section{A Curious Paradox}

Allowance for di-electronic recombination removes some discrepancies between observations and earlier calculations of the ionisation equilibria in nebulae. Others have been removed by taking account of charge-transfer with hydrogen, $\mathrm{X}^{+}+\mathrm{H}=\mathrm{X}+\mathrm{H}^{+}$, for which empirical studies have been made by $D$. Péquignot of the Paris Observatory and quantal calculations have been made by A. Dalgarno and collaborators at Harvard. In nebulae, most of the hydrogen is ionised but it is a curious paradox lexplained in terms of the $\lambda^{3}$ dependence of the hydrogen photo-ionisation cross-section) that the fraction of neutral $\mathrm{H}$ can be larger for a high-excitation nebula, photo-ionised by a very hot star. The charge-transfer process is found to be particularly important in nebulae of high excitation.

\section{Further Reading}

Blackwell D.E., "Stellar Atmospheres and Laboratory Astrophysics", Quart. J. R. Astr. Soc., 15 (1984) 224.

Atoms in Astrophysics, ed. P.G. Burke, W.B. Eissner, D.G. Hummer and I.C. Percival (Plenum Press) 1983.

Seaton M.J., "Atoms, Astronomy and Aeronomy", Quart. J. R. Astr. Soc., 23 (1982) 2.

\section{Hewlett-Packard Europhysics Prize}

The 1985 Hewlett-Packard Europhysics Prize has been awarded equally to Dr. Jens A. Als-Nielsen of the Risø National Laboratory, Roskilde, Denmark and Dr. Michael Pepper of the Cavendish Laboratory, Cambridge and the GEC Hirst Research Centre, Wembley, England, for "their contributions to the experimental study of low-dimensional physics". The presentation will be made at the 5th CMD Conference in Berlin (see above).

\title{
5th EPS CMD General Conference in Berlin (West)
}

The annual general conferences of the Condensed Matter Division are developing very successfully.

After the "new beginnings" with the first general conference in Antwerp (1980) (see Europhysics News, May, 1980) with over 600 participants, the question was whether such a Conference could be held on a regular basis as a kind of European counterpart to the March Meeting of the American Physical Society. Those that followed in Manchester (1982), Lausanne (1983), Den Haag (1984) have confirmed the need. The number of participants has remained at over 600 .

The 1984 Conference in Den Haag with Prof. F. Mueller as Chairman and Prof. P. Wyder as Chairman of the Programme Committee offered outstanding plenary talks and symposia, starting with R. Schrieffer's talk on solitons in condensed matter and closing with $\mathrm{G}$. 't Hooft's talk which reviewed techniques and concepts common to condensed matter physics and elementary particle theory. Other plenary speakers were Siegbahn, de Gennes, Benedek, Geballe, Hilsum, Binnig. Several of the symposia created a great deal of enthusiasm, and in particular the one on the quantum Hall effect (von Klitzing and fractional).

The 5th General Conference will take place in Berlin from March 18-22, 1985. Sessions will be held in the buildings of the Physics Department of the Technical University in Berlin - Charlottenberg. Just as The Institute of Physics did in 1982, the German Physical Society has agreed to cancel its 1985 "Frühjahrstagung" to act as host for the organization of the Conference.

Under the chairmanship of Prof. J. Treusch and with Prof. M. Cardona as Programme Committee Chairman, the 5 th General Conference holds great promise with close to 1000 contributed papers and an exciting plenary programme and symposia on recent developments. The number of suggestions which were made to the Programme Committee for invited papers was indeed impressive; research in condensed matter physics is doing well in Europe.

We look forward to a great meeting.

\section{J.T. Devreese}

Chairman of the Condensed Matter Division

\section{University of Antwerp Rijksuniversitair Centrum}

Chair for Theoretical and Mathematical Physics

\section{Post-doctoral Research Associate}

There is a vacancy for a theoretical physicist or chemist to join the theoretical physics research group which is involved in the detailed investigation of non-adiabatic effects in molecules. The main task of the applicant will be to extend existing computer codes for the treatment of near electronic degeneracies.

Applicants should have a good knowledge of the quantum theory of molecules and thorough experience with large scale electronic structure calculations.

The appointment will be made for the period of 1 year at the level of post-doctoral research associate with a salary of about $950.000 \mathrm{BF}$ per annum.

Applications with curriculum vitae (and major publications) should be sent as soon as possible to

Prof. Dr. P. VAN LEUVEN, Dienst Teoretische en Wiskundige Natuurkunde Rijksuniversitair Centrum Antwerpen, Groenenborgerlaan 171, B - 2020 Antwerpen

EPS Divisions, Sections and Group

Astronomy and Astrophysics Division Solar Physics Section

Atomic and Molecular Physics Division

Atomic Spectroscopy Section

Chemical Physics

Chemical Physics
Electronic and Atomic Collisions

Molecular Physics

Computational Physics Group

Condensed Matter Division

Liquids Section

Low Temperature Physics Section

Macromolecular Physics

Magnetism

Magnetism

Serniconductors and Insulators

Surfaces and Interfaces

High Energy \& Particle Physics Division

Nuclear Physics Division

Optics Division

Plasma Physics Division

Quantum Electronics Division
Europhysics News is the official journal of the European Physical Society which comprises 29 National Societies, Academies and Group, over 3500 Individual Mem. bers and 66 Associate Members. Governing bodies of EPS are the General Meeting. Council and an elected Executive Committee responsible for detailed policy. EPS promotes the collaboration of physicists throughout Europe, organising and harmonising conferences and publications, improving physics education, encouraging physics applications, awarding scholarships to sponsored schools in Erice. EPS publishes in addition to EN, Europhysics Conference Abstracts, E. Ed. News and, in collaboration with The Institute of Physics (UK), the European Journal of Physics. Individual Members receive EN free of charge (price to institutions: Sw.Fr. $90 .-/ a)$, rebates on the price of many publications and on conference fees. Annual EPS membership fee for Individual Members belonging to an EPS member society is: Sw.Fr. 40,-; independent members: Sw.Fr. 120.-; members of a Collaborating Society, e.g. the American Physical Society: Sw.Fr. 50- (\$25).

\author{
Editor: E.N. Shaw \\ Meetings Compilation: W.S. Newman \\ Editorial Board: \\ K. Appert, A. Baratoff, B. Jacrot. \\ G.R. Macleod, M. Mayor, J. Muller \\ Editorial and Advertising Office at the EPS \\ Secretariat \\ Address: EUROPEAN PHYSICAL SOCIETY \\ P.O. Box 69. \\ CH-1213 Petit-Lancy 2 \\ Switzerland \\ Telephone: Geneva (22) 931130 \\ Telex: 423455 dema ch \\ Cables: europhys genève \\ Printed by: Pfirter frères s: \\ CH-1213 Petit-Lancy/Switzerland
}

